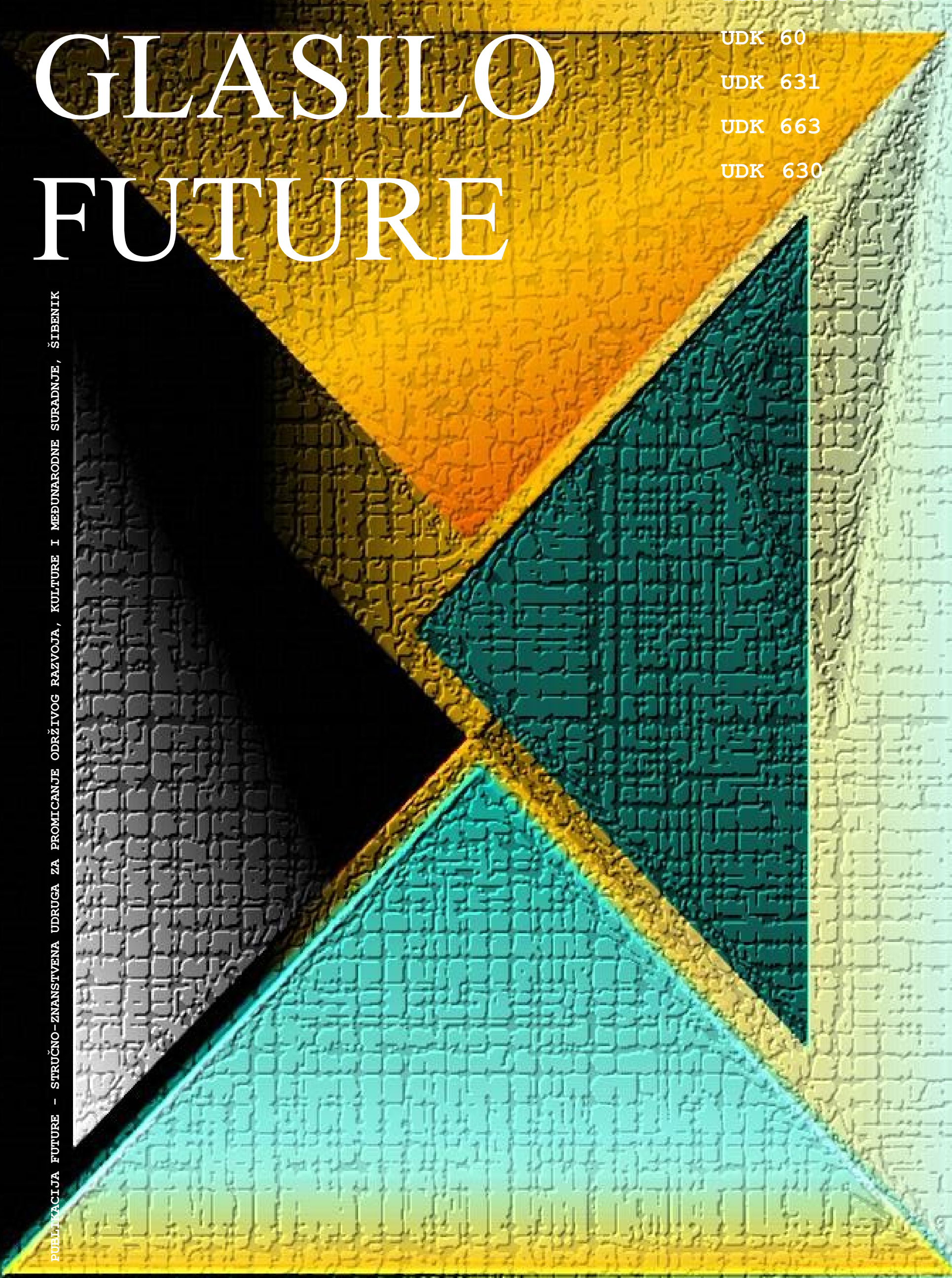

VOLUMEN 2 BROJ 5-6

PROSINAC 2019. 


\section{Glasilo Future}

\section{Stručno-znanstveni časopis}

Nakladnik:

FUTURA

\section{FuTURA}

Sjedište udruge: Šibenik

\section{Adresa uredništva:}

Bana Josipa Jelačića 13 a, 22000 Šibenik, Hrvatska / Croatia

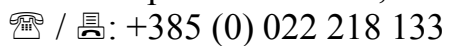

凶: urednistvo@gazette-future.eu / editors@gazette-future.eu

(3): www.gazette-future.eu

Uređivački odbor / Editorial Board:

Doc. dr. sc. Boris Dorbić, v. pred. - glavni i odgovorni urednik / Editor-in-Chief

Emilija Friganović, dipl. ing. preh. teh., v. pred. - zamjenica g. i o. urednika / Deputy Editor-in-Chief

Ančica Sečan Matijaščić, mag. act. soc. - tehnička urednica / Technical Editor

Antonia Dorbić, mag. art. - zamjenica tehničke urednice / Deputy Technical Editor

Prof. dr. sc. Željko Španjol

Mr. sc. Milivoj Blažević

Vesna Štibrić, dipl. ing. preh. teh.

Međunarodno uredništvo / International Editorial Board:

Prof. dr. sc. Kiril Bahcevandziev - Portugalska Republika (Instituto Politécnico de Coimbra)

Prof. dr. sc. Martin Bobinac - Republika Srbija (Šumarski fakultet Beograd)

Prof. dr. sc. Zvezda Bogevska - Republika Sjeverna Makedonija (Fakultet za zemjodelski nauki i hrana Skopje)

Dario Bognolo, mag. ing. - Republika Hrvatska (Veleučilište u Rijeci)

Prof. dr. sc. Agata Cieszewska - Republika Poljska (Szkoła Główna Gospodarstwa Wiejskiego w Warszawie)

Dr. sc. Bogdan Cvjetković, prof. emeritus - Republika Hrvatska (Agronomski fakultet Zagreb)

Prof. dr. sc. Duška Ćurić - Republika Hrvatska (Prehrambeno-biotehnološki fakultet Zagreb)

Prof. dr. sc. Margarita Davitkovska - Republika Sjeverna Makedonija (Fakultet za zemjodelski nauki i hrana Skopje)

Prof. dr. sc. Dubravka Dujmović Purgar - Republika Hrvatska (Agronomski fakultet Zagreb)

Prof. dr. sc. Josipa Giljanović - Republika Hrvatska (Kemijsko-tehnološki fakultet u Splitu)

Prof. dr. sc. Semina Hadžiabulić - Bosna i Hercegovina (Agromediteranski fakultet Mostar)

Prof. dr. sc. Péter Honfi - Mađarska (Faculty of Horticultural Science Budapest)

Prof. dr. sc. Valeria Ivanova - Republika Bugarska (Fakultet za lozaro - gradinarstvo Plovdiv)

Prof. dr. sc. Mladen Ivić - Bosna i Hercegovina (Univerzitet PIM)

Doc. dr. sc. Orhan Jašić - Bosna i Hercegovina (Filozofski fakultet Tuzla)

Prof. dr. sc. Tajana Krička - Republika Hrvatska (Agronomski fakultet Zagreb)

Doc. dr. sc. Dejan Kojić - Bosna i Hercegovina (Univerzitet PIM)

Slobodan Kulić, mag. iur. - Republika Srbija (Srpska ornitološka federacija i Confederation ornitologique mondiale)

Prof. dr. sc. Biljana Lazović - Crna Gora (Biotehnički fakultet Podgorica)

Prof. dr. sc. Branka Ljevnaić-Mašić - Republika Srbija (Poljoprivredni fakultet Univerziteta u Novom Sadu)

Doc. dr. sc. Zvonimir Marijanović - Republika Hrvatska (Kemijsko-tehnološki fakultet u Splitu)

Doc. dr. sc. Ana Matin - Republika Hrvatska (Agronomski fakultet Zagreb)

Prof. dr. sc. Bosiljka Mustać - Republika Hrvatska (Sveučilište u Zadru)

Hrv. akademik prof. dr. sc. Stanislav Nakić - Bosna i Hercegovina (Sveučilište Hercegovina Mostar)

Sandra Popović, mag. ing. - Republika Srbija (Poljoprivredni fakultet Beograd)

Doc. dr. sc. Bojan Simovski - Republika Sjeverna Makedonija (Fakultet za šumarski nauki, pejzažna arhitektura i

ekoinženering "Hans Em" Skopje)

Prof. dr. sc. Davor Skejić - Republika Hrvatska (Građevinski fakultet Zagreb)

Doc. dr. sc. Milan Stanković - Republika Srbija (Univerzitet u Kragujevcu)

Akademik prof. dr. sc. Refik Šećibović - Bosna i Hercegovina (Visoka škola za turizam i menadžment Konjic)

Prof. dr. sc. Andrej Šušek - Republika Slovenija (Fakulteta za kmetijstvo in biosistemske vede Maribor)

Prof. dr. sc. Elma Temim - Bosna i Hercegovina (Agromediteranski fakultet Mostar)

Mr. sc. Merima Toromanović - Bosna i Hercegovina (Biotehnički fakultet Univerziteta u Bihaću)

Doc. dr. sc. Ivana Vitasović Kosić - Republika Hrvatska (Agronomski fakultet Zagreb)

Doc. dr. sc. Ana Vujošević - Republika Srbija (Poljoprivredni fakultet Beograd)

Prof. dr. sc. Vesna Židovec - Republika Hrvatska (Agronomski fakultet Zagreb)

Lektura i grafička priprema: Ančica Sečan Matijaščić, mag. act. soc.

Objavljeno: 31. prosinca 2019. godine.

Časopis izlazi u elektroničkom izdanju dva puta godišnje, krajem lipnja i prosinca, a predviđena su i dva interdisciplinarna specijalna izdanja

tijekom godine iz STEM i ostalih znanstvenih/umjetničkih područja.

C̆asopis je besplatan. Rukopisi i recenzije se ne vraćaju i ne honoriraju.

Umnožavanje (reproduciranje), stavljanje u promet (distribuiranje), priopćavanje javnosti, stavljanje na raspolaganje javnosti odnosno prerada u bilo kojem obliku nije dopuštena bez pismenog dopuštenja Nakladnika.

Sadržaj objavljen u Glasilu Future može se slobodno koristiti u osobne i obrazovne svrhe uz obvezno navođenje izvora. 


\section{Glasilo Future}

\section{Stručno-znanstveni časopis}

FUTURA - stručno-znanstvena udruga za promicanje održivog razvoja, kulture i međunarodne suradnje, Bana Josipa Jelačića 13 a, 22000 Šibenik, Hrvatska

(2019) $2(5-6)$ 01-72

\section{SADRŽAJ:}

Izvorni znanstveni rad (original scientific paper)

Str.

Ivana Gašparović, Ž. Španjol, B. Dorbić, I. Tolić, Irena Milčić

Perivoj dvorca Kulmer-Bračak (Republika Hrvatska) - biološko i prostorno vrednovanje The public garden of the Kulmer-Bračak Castle (The Republic of Croatia) - biological and spatial evaluation

Emilija Friganović, Nikolina Tokmakčija, Ančica Sečan Matijaščić, M. Kelava, Mladenka Šarolić, B. Dorbić

Salmonella spp. in RASFF notifications involving Croatia in the period from 01/01/2014 to $31 / 12 / 2018$

T. Svalina, Sara Nasić, M. Šuste, Žana Delić, Emilija Friganović, Mladenka Šarolić, B.

Dorbić

Aromatski profil kupinovih vina

Aromatic profile of blackberry wines

Mladenka Šarolić, Nikolina Bosnić, Emilija Friganović, Žana Delić, M. Šuste, T. Svalina, B.

Dorbić, Z. Marijanović

Kemijska analiza hlapljivih spojeva tradicionalne rakije Anižete s otoka Korčule - Republika Hrvatska

Chemical analysis of volatile compounds of traditional brandy Anižeta from the island of Korčula - Republic of Croatia

\section{Stručni rad (professional paper)}

Doroteja Benko, Ivana Vitasović-Kosić

Primjena utilitarnog i ukrasnog bilja u razdoblju baroka na primjeru dvoraca Hrvatskog zagorja

Use of utilitarian and ornamental plants in the Baroque period on the example of castles in Hrvatsko zagorje 
Doroteja Benko, Ivana Vitasović-Kosić / Primjena utilitarnog i ukrasnog bilja u razdoblju baroka na primjeru dvoraca Hrvatskog Zagorja / Glasilo Future (2019) 2 (5-6) 58-70

\title{
Primjena utilitarnog i ukrasnog bilja u razdoblju baroka na primjeru dvoraca
}

\section{Hrvatskog zagorja}

\section{Use of utilitarian and ornamental plants in the Baroque period on the example of castles in Hrvatsko zagorje}

\author{
Doroteja Benko ${ }^{1}$, Ivana Vitasović-Kosić ${ }^{2 *}$
}

stručni rad (professional paper)

doi: $10.32779 /$ gf.2.5-6.5

\section{Sažetak}

Čovjek je biljke kroz povijest koristio za različite svrhe. Od prapovijesti pa nadalje, određene biljke zauzimaju važnu ulogu u životu čovjeka, neke od njih su korištene u utilitarne svrhe. U Egiptu su formirali voćne drvorede kako bi okružili svoj posjed, pritom ne narušavajući osnovnu ideju simetrije. U Antici su izrađivali kapitele (glave stupova) prikazujući pojedine biljne vrste, a u Srednjem su vijeku najčešći motivi u bordurama ili u prikazima svetaca i nekih događaja Kršćanske vjere. Za vrijeme baroka perivoji doživljavaju procvat zahvaljujući moćnim europskim vladarima što su perivoj koristili kao prikaz svoje moći. Ovime se ujedno dotičemo simbolike bilja i primjera baroka iz Hrvatskog zagorja. Isto razdoblje, ali drugačiji gospodarski i klimatski uvjeti uzrokovali su razlike u primjeni i odabiru vrsta. Proučavanjem različite literature o dvorcima Hrvatskog zagorja sastavljen je popis korištenih biljnih vrsta od kojih se najčešće spominju: divlji kesten (Aesculus hippocastanum L.), šimšir (Buxus sempervirens L.), obični grab (Carpinus betulus L.), katalpa (Catalpa bignonioides L.) te rodovi smreka (Picea sp.), duglazija (Pseudo tsuga sp.) i platana (Platanus sp.).

Ključne riječi: primjena bilja, krajobrazna arhitektura, barok, Hrvatsko zagorje.

\begin{abstract}
Man has used plants throughout history for various purposes. From prehistoric times onwards, certain plants play an important role in human life, some of which have been used for utilitarian purposes. In Egypt, they formed fruit trees to encircle their property, without disturbing the basic idea of symmetry. In ancient times, capitals (column heads) were made, showing individual plant species, and in the

\footnotetext{
${ }^{1}$ Uni. bacc. prosp. arch., studentica Ms. studija Krajinska Arhitektura, Biotehniška fakulteta, Univerza v Ljubljani

2 Sveučilište u Zagrebu Agronomski fakultet, Zavod za poljoprivrednu botaniku, Svetošimunska cesta 25, 10000 Zagreb, Republika Hrvatska.

* E-mail: ivitasovic@agr.hr
} 
Middle Ages the most common motifs were in borders or in depictions of saints and some events of the Christian faith. During the Baroque, gardens are flourishing thanks to powerful European rulers who used the park as a display of their power. This also touches on the symbolism of plants and examples of Baroque from the Croatian Zagorje. The same period, but different economic and climatic conditions caused differences in use and selection of plant species. A study of the various literature on castles in Hrvatsko Zagorje has compiled a list of the most commonly used plant species: wild chestnut (Aesculus hippocastanum L.), boxwood (Buxus sempervirens L.), common hornbeam (Carpinus betulus L.), catalpa (Catalpa bignonioides L.), and genera of spruce (Picea sp.), duglasia (Pseudotsuga sp.) and plane (Platanus sp.).

Key words: use of plants, landscape architecture, baroque, Hrvatsko zagorje.

\section{Uvod}

Utilitarne i ukrasne biljke su sastavni dio života ljudi, od davnina su se koristile na različite načine. Neki smatraju da je uzgoj bilja nagonska potreba, međutim čovjeku nije svrsishodan samo utilitaran vrt, već i reprezentativan vrt (The Royal horticultural society, 1992). Osim proizvodnje kisika tijekom procesa fotosinteze, uloga biljaka je znatno veća (Pađan, 2012). Kroz povijest, bilježile su se biljne vrste u dnevnicima istraživača različitih interesa i struka, što danas omogućava lakši uvid u korištenje biljnog materijala.

Dok u baroknoj Europi vidimo utjecaj povijesnih događanja, postavlja se pitanje vrijede li ista "pravila" za tadašnju rascjepkanu Hrvatsku. Geografski blizu tadašnjim silama, Hrvatska je zbog svog položaja podijeljena na upravljanje različitih zemalja pa tako Hrvatsko zagorje pripada AustroUgarskoj. Ista vlast, ali različita lokalna ekonomska situacija omogućile su Hrvatskom zagorju spori razvoj, prilagođenu utilitarnu upotrebu, te skromno korištenje ukrasnog bilja u odnosu na druge dijelove tadašnje Monarhije.

Cilj ovoga stručnog rada bio je proučiti povijesnu vrijednost vrta, upotrebe utilitarnih i ukrasnih biljnih vrsta od prapovijesti do baroka, te na primjeru dvoraca Hrvatskog zagorja istražiti razdoblje baroka s velikim značajnim vrtovima i novim biljnim elementima u krajobraznoj arhitekturi.

\section{Vrijednost vrta i biljnih vrsta prema različitoj svrsi i korištenju}

Vrt omogućuje drugačiji, puniji, zanimljiviji i raznolikiji način života. Sastavljen je od više strukturnih elemenata. Privlačan je svima neovisno o dobi, statusu ili o imovinskom stanju vlasnika vrta te tako postaje vrijednost. Prilagođena klasifikacija prema Aničić (2017) prikazana u slijedu daje nam uvid kako vrt, ali i širi pojam krajobraz utječu na sva polja našeg života i obuhvaćaju sve navedene vrijednosti: 
1. boravišna vrijednost - vrt nadopunjuje stanovanje, njegova je vrijednost predodređena povezanošću boravišnih prostora u kući s vanjskim prostorom;

2. ekološka vrijednost - povećava biološki potencijal grada, prirodna građa pridonosi pojedincu psihičku i fizičku vrijednost, općenito se pojedinac bolje osjeća;

3. socijalna vrijednost - u vrtu se odvijaju druženja, svakodnevni obiteljski život, dobivamo povezanije susjedstvo, ali opet može pružiti osamu i izolaciju;

4. psihološka vrijednost - boravak u vrtu doprinosi emocionalnom i tjelesnom oporavku, zdravlju i kondiciji;

5. razvijanje kreativnosti - uređuje se ili oblikuje prema osobnim idejama i ukusu, postaje odraz pojedinca ili skupine koja taj vrt koristi;

6. estetska vrijednost - čovjek ima potrebu izraziti vrijednost prema ljepoti, složenosti i šarolikosti okolice;

7. gospodarska vrijednost - uzgoj voćnih i povrtlarskih kultura;

8. rekreativna vrijednost - vrt omogućuje rad i uzgoj bilja, gdje se čovjek ponovno aktivira;

9. terapijska vrijednost - za psihički i fizički boljitak osoba u nepovoljnom položaju, isključenih skupina poput djece s teškoćama, osoba s invaliditetom, starijih osoba ili onih osoba koje imaju problema s različitim oblicima ovisnosti.

\section{Primjena biljnih vrsta kroz povijest}

Prve značajnije primjene bilja uočavamo u Egiptu. Egipćani su sadili vrtove bogate raznovrsnim vrsta cvijeća i ostalog bilja, kojim su krasili domove, ulice, trgove, svetišta, darovali ga bližnjima, njime častili visoke uzvanike, pratili umrle na put u onaj svijet i darivali ga bogovima (Germ, 2002). Neki od primjera su stupovi koji oponašaju oblik debla stabla i svežnja povezanih biljnih stabljika. Prema Pađanu (2012) tri su stilska reda stupova: a) oblik palme - okrugli stup s kapitelom u obliku palmina cvijeta, b) oblik lotosa - stup s kružno povezanim stabljikama i kapitel kao lotosov cvijet i c) oblik papirusa - okrugli stup od stegnutih žila i kapitela u obliku biljke papirusa.

Egipćani su osim toga razvili linijski sustav biljnog materijala - drvorede. U početku su to bili samo utilitarni (korisni) vrtovi jabuka (Malus domestica Borkh.), šljiva (Prunus domestica L.) i sl., a kasnije su upotrebljavali autohtonu floru pojedinog podneblja (rodovi Tamarix, Phoenix itd.). Složeniji vrtovi, koji su imali više bazena, odnosno ribnjaka, sadržavali su vodeno bilje. Uz bazen razvila se pergola koju su koristili za razvoj vinove loze (Vitis vinifera) (Aničić, 2017). U Mezopotamiji se razvio simptomatični kult - sveto drvo, kao simbol plodnosti zemlje i razvitka života. Najpoznatiji su Semiramidini vrtovi (Slika 1.) gdje se terase kaskadno uzdižu s dekorativnom svrhom.

Grčka je koristila kapitel korintskog stupa kojem je akantovo lišće (Acanthus mollis L.) zaslužno za oblikovanje (Pađan, 2012). U vrtovima su primjenjivali biljne vrste i cvjetno grmlje, kao npr. drveće oraha (Juglans regia L.) i voćaka (porodica Rosaceae), lovor (Laurus nobilis L.), mirtu (Myrtus communis L.), bršljan (Hedera helix L.) i kao posebnu inspiraciju ružu (rod Rosa). Sa sličnom klimom 
Doroteja Benko, Ivana Vitasović-Kosić / Primjena utilitarnog i ukrasnog bilja u razdoblju baroka na primjeru dvoraca Hrvatskog Zagorja / Glasilo Future (2019) 2 (5-6) 58-70

rimska je kuća imala manji komad obradive površine za osobne potrebe - heredium, koji ju je u cijelosti okruživao, a uzgajalo se voće, povrće i ljekovito bilje. Peristil je bio reprezentativan prostor s bogatije uređenim vrtom gdje se boravilo za vrijeme visokih ljetnih temperatura. Cvijeća toliko nije bilo, ali je zato prostor bio ukrašavan grmljem i manjim drvećem autohtona podrijetla kao primjerice bršljan: (Hedera helix), šimšir (Buxus sempervirens), lovor (Laurus nobilis), mirta (Myrtus communis), rodovi Acanthus, ružmarin (Rosmarinus), kadulja (Salvia), udikovina (Viburnum), ruža (Rosa) i sl. (Aničić, 2017). Vazdazelene vrste su koristili kako bi vrt izgledao jednako cijele godine, a simbolički vazdazelene vrste označavaju besmrtnost i vječnost života (Germ, 2002). Za sjenu koristili su drveća velikih krošanja, platanu (Platanus orientalis L.) i maslinu (Olea europaea L.) (Aničić, 2017). U romaničkim crkvama i katedralama uzimaju rozetu (Slika 2.) kao prozorski element dekoracije u obliku cvijeta ivančice (Slika 2.) sa stiliziranim laticama.

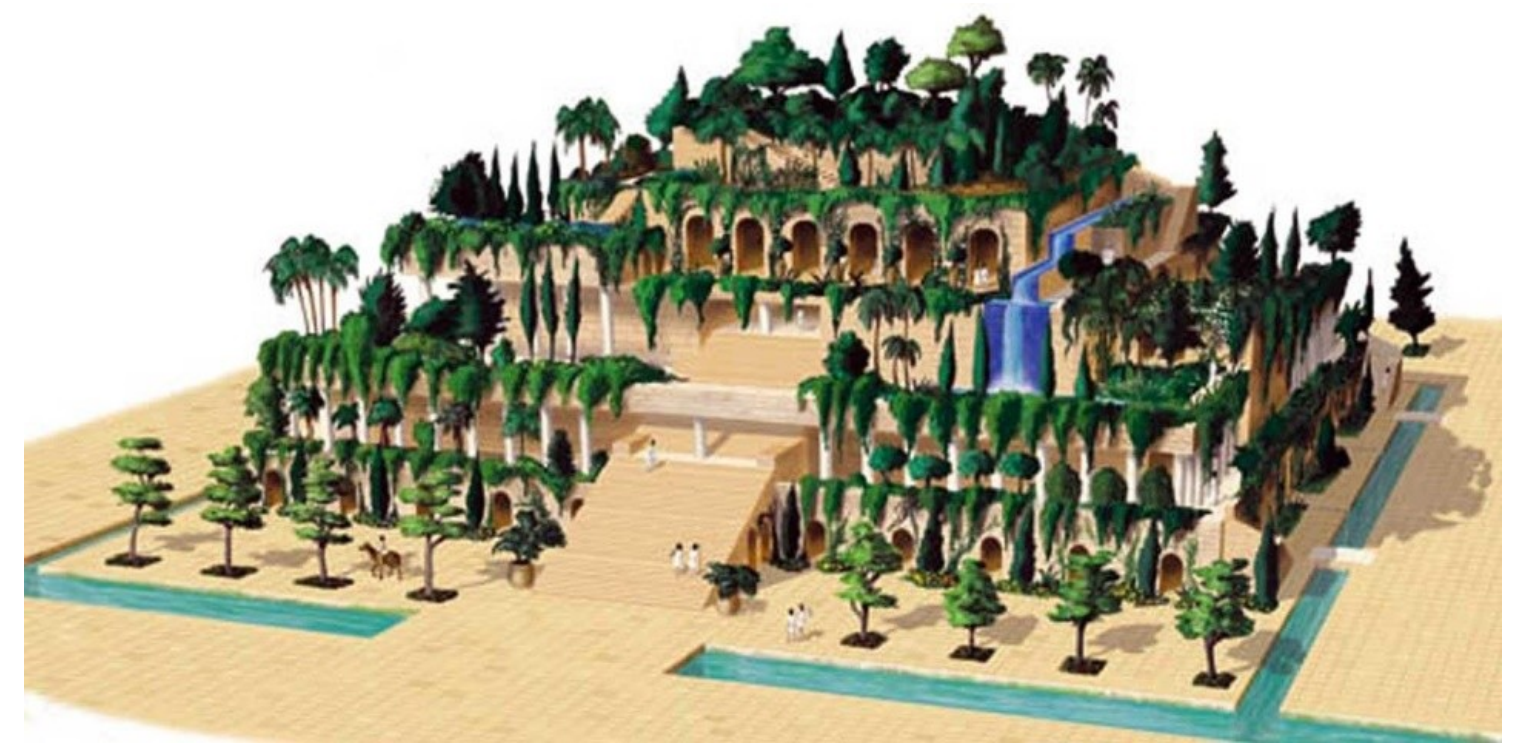

Slika 1. Semiramidini vrtovi (https://www.starapovijest.eu/viseci-vrtovi-babilona/).

Figure 1. Semiramidine Gardens (https://www.starapovijest.eu/viseci-vrtovi-babilona/).

U razdoblju gotike je najsmjelije izrađen diktat uzdizanja od tla, a unutarnja kamena rebra posve logično podsjećaju na biljne elemente. Gotičke crkve popularno kazano " prepričavaju biblijske priče" putem likovnih kompozicija i istih simboličkih znakova, u kojima su biljni likovi nezamjenjiv dio umjetničkog prikaza (Pađan, 2012).

Sveto pismo spominje mnogo biljnih vrsta. U evanđeoskim prilikama metaforičko značenje nalazi maslina (Olea europaea), smokva (Ficus carica), vinova loza (Vitis vinifera), rodovi ljiljan (Lilium), ruža (Rosa) i dr. (Forum, 2009). Mnogi su cvjetovi ušli u svetačke legende i dobili ulogu " atributa svetaca" (Germ, 2002). 


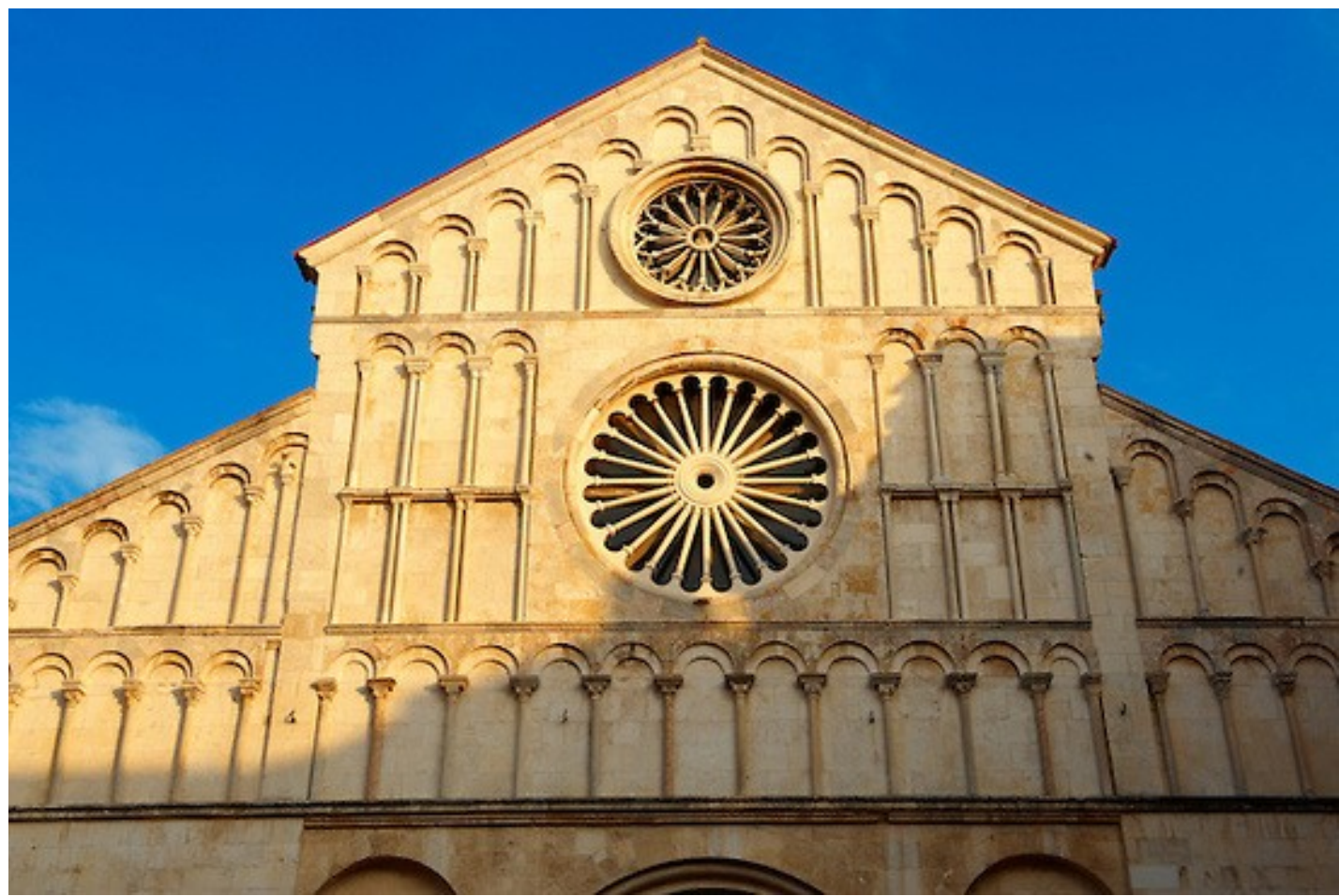

Slika 2. Rozeta na katedrali sv. Stošije u Zadru, 13. stoljeće

(Izvor: http://dream-croatia.com/wp-content/uploads/2014/03/katedralasveteanastazije.jpg?x1 1058).

Figure 2. Rosette at the Cathedral of Sts. Stošija in Zadar, 13th Century

(Source: http://dream-croatia.com/wp-

content/uploads/2014/03/katedralasveteanastazije.jpg?x11058).

Nakon renesanse i klasicizma u 18. st. barok mijenja jasnoću u bizarne i izokrenute oblike, u stil pokreta i strasti. Arhitektura baroka teži ka raskoši, sjaju i pretjeranom ukrašavanju. Prema Ogrinu (1993) u krajobraznoj arhitekturi karakteristike baroka su parteri povezani na središnju os i njegovi dijelovi koji dodatno povezuju cjelinu prostora. Osni koncept učvršćuje trodijelni razvoj u uzdužnom smjeru, te kroz njega geometrijska perspektiva stvara dojam prenašanja unutarnjeg poretka vrta $u$ kozmički poredak. Voda, u obliku zrcalnih ploha, projicira okolni prostor (najčešće biljni materijal) stvarajući veću kompleksnost prostora. Izbjegavala se simetrija na različitim područjima umjetnosti, ali za vrtnu umjetnost Francuske ona dobiva posebnu ulogu cara Luja XIV. "Force la Nature" prilično opisuje apsolutnu vlast gdje on svojim primjerom, izgradnjom dvorca Versailles (Slika 3.), nadvladava prirodu što je vidljivo u tlocrtu. Sve preinake prostora kako bi nastao ovaj park (već spomenuta simetričnost u rasporedu elemenata, provođenje staza i kanalica, vodoskoci, skulpture, modelacije terena itd.) opisuju njegovu moć koju nije imao svatko. Simetrija je bila simbol monističke društvene moći. Dvorac Versailles napušta gradski prostor i njegove zadane mjere te se okreće krajobrazu u kojem ostvaruje svoju mjeru (Marković, 1995):

Od središta određenog zgradom dvorca simetrično se širi mreža aleja i šetnica koje povezuju različite parkom rasprostranjene sadržaje: fontane s vodotocima, pravilno oblikovane goleme vodene površine, paviljonske građevine, vidikovce, raslinjem oblikovane labirinte $i$ scenično komponirane grupe skulptura, sve do udaljenih šuma namijenjenih lovu. 
Simetrija se naglašavala izduženom osi u sredini, a bogat i kompleksan rječnik oblikovanja taj cijeli kompleks čini raskošnim i dostojnom tituli "nebrušenog bisera", s druge strane sve je to u takvoj mjeri da nadilazi neizmjerno što možemo povezati s baroknim kičem (Marković, 1995). Ova se raskoš odnosi i na odabir ukrasnog bilja gdje je raznovrsnost biljaka vrlo velika, od autohtonih pa do egzotičnih vrsta nabavljenih iz koloniziranih zemalja. No, prema Ogrin (1993) ono što najčešće srećemo posjećujući vrtove baroknog stila, a bile su od samog početka, svakako je rod lipa (Tilia sp.). Takve primjere nalazimo u vrtovima: Chams-sur-Marne, Rambouillet i Rosny.

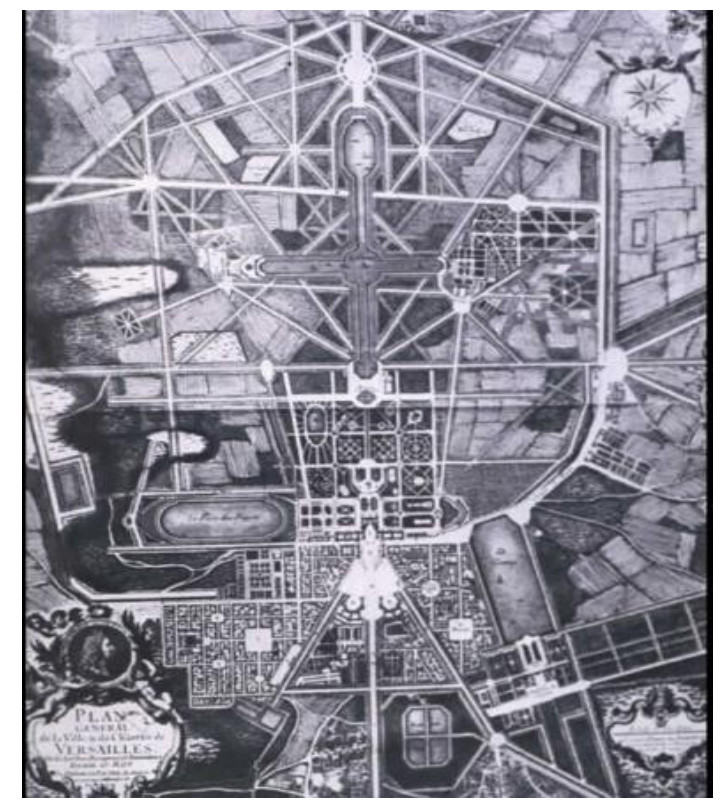

Slika 3. Versailles, Izvor: Barok, Francuska 2018 (Iva Rechner Dika, Razvoj krajobraznog planiranja). Figure 3. Versailles, source: Baroque, France 2018 (Rechner Dika, 2015).

\section{Karakteristike baroka kontinentalne Hrvatske na primjerima Hrvatskog zagorja}

Najznačajniji udio dvoraca i njihovih perivoja na području kontinentalne Hrvatske, radi svoje brojnosti, zauzimaju dvorci Hrvatskog zagorja. Na samo oblikovanje utjecala je jaka lokalna tradicija feudalnog društva. Feudalci su gradili skromnije dvorce bez pretjerane raskoši na dijelu kontinentalne Hrvatske. Prostorni red, koji je prisutan u Versaillesu, nije bio moguć u dvorcima Hrvatskog zagorja zbog njegove podvojene uloge gospodarske i stambene/ladanjske (Šćitaroci, 2005).

Prema Marković (1995) gospodarski su objekti bili ogoljeni, svedeni na jednostavnu geometrijsku formu, a geometrijski se park morao prilagoditi krajoliku, što je više izgledalo kao slobodno grupiranje. Također, bilo je potrebno proširiti pogled na okolni prirodni krajobraz kako bi se dobila cjelovita slika tog prostora. Naspram ostatka Austro-Ugarske monarhije, društvene su neprilike na području Hrvatskog Zagorja utjecale na kasno pojavljivanje baroknog stila. Tako barokno razdoblje u Hrvatskoj dijelimo na: rani barok tijekom 17. stoljeća gdje prevladava sakralna umjetnost i na barok 18. stoljeća - profana arhitektura (Marković, 1995).

Na temelju nacrta parka dvorca Gornje Bistre, Marković (1995) razjašnjava hrvatski barokni stil 
(Slika 4.) koji prikazuje tlocrtni položaj zgrada i park tog istog dvorca. U legendi plana spominju se sadržaji: spremnici za led, domaćinske zgrade, mlin, boravište portira, straže, povrtnjak i voćnjak, ali nema elemenata ladanjske organizacije parka (vrtni paviljoni, natkrite šetnice, intimna područja ograđena raslinjem i sl.) što nam je potvrda kako su doista parkovi bili gospodarske i stambene namjene. Sustav za navodnjavanje povrtnjaka i voćnjaka nalazio se na rubu s umjetnim jezerom, a jedina je točka u središtu vodoskok koji je okružen zidinama dvorca, shodno europskom baroku u kojem je nositelj kompozicije voda. Reprezentativni sadržaji su umanjeni, a gospodarske namjene ne narušavaju njihov sklad i pravilnu prostornu organizaciju. One su smještene u pačetvorinasto (konkavan oblik) složenim nizovima gredica. Takav primjer rasporeda povrtnjaka i voćnjaka vidljiv je u perivojima dvoraca Miljana, Popovača i Bela I, a unose dinamiku u vanjski prostor.

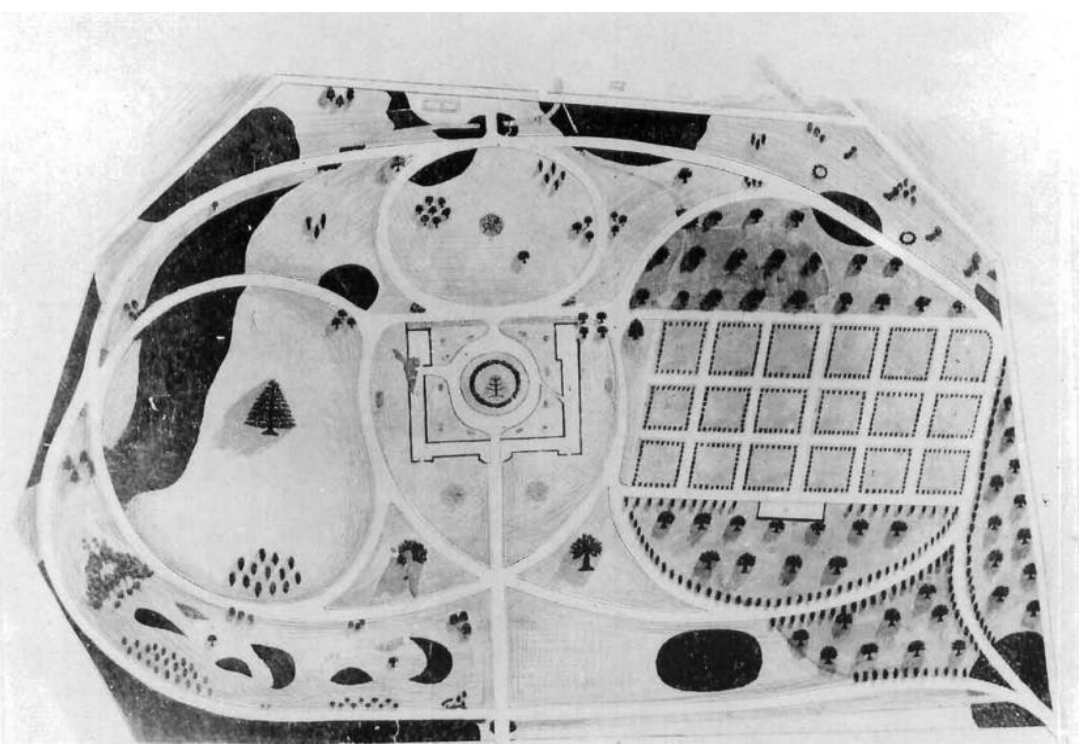

Slika 4. Nacrt parka dvorca Gornja Bistra (preuzeto iz Marković (1987).

Figure 4. Draft of Gornja Bistra castle park (taken from Marković (1987).

\section{Najčešće biljne vrste korištene u perivojima dvoraca Hrvatskog zagorja}

Za literaturno istraživanje najčešćih biljnih vrsta uzeti su primjeri iz perivoja dvoraca Hrvatskog zagorja prema Šćitaroci (2005), a podijeljeni su po vremenu nastanka. Tako su u 17. stoljeću izgrađeni: 1. Bajnski dvori, 2. Gorica, 3. Klenovnik i 4. Velika Horvatska, a u 18. stoljeću izgrađeni su: 5. Bela II., 6. Bežanec, 7. Gornja Bedekovčina, 8. Gredica, 9. Jakovlje, 10. Lužnica, 11. Novi Marof, 12. Opeka, 13. Donje Oroslavje, 14. Popovec, 15. Stubički Golubovec, 16. Šaulovec, 17. Veliki Bukovec, 18. Začretje i 19. Zajezda. Izrađen je popis biljaka (Tablica 1.) koji je sakupljen uz pomoć različite dostupne stručne i znanstvene literature. Uspoređeno je koliko se puta vrste spominju i/ili ponavljaju. S obzirom na mogućnost da se u izvorima ne spominju sve biljne vrste, moguće je da ovaj popis nije konačna lista biljnih vrsta koje su tada bile korištene. Za detaljnije istraživanje biljnih vrsta opisani su perivoji Opeka i Golubovec. 
Doroteja Benko, Ivana Vitasović-Kosić / Primjena utilitarnog i ukrasnog bilja u razdoblju baroka na primjeru dvoraca Hrvatskog Zagorja / Glasilo Future (2019) 2 (5-6) 58-70

Tablica 1. Popis biljaka korištenih u perivojima dvoraca Hrvatskog Zagorja (prema: Šćitaroci, 2005)

Table 1. List of plants used in the gardens in Hrvatsko Zagorje (according to: Šćitaroci, 2005).

\section{Latinska imena biljaka}

1. Abies nordmanniana (Steven) Spach

2. Abies $\mathrm{sp}$.

3. Acer campestre $\mathrm{L}$.

4. Acer negundo L.

5. Acer palmatum Thunb.

6. Acer platanoides L.

7. Aesculus hippocastanum L.

8. Ampelopsis $\mathrm{sp}$.

9. Buxus sempervirens $\mathrm{L}$.

10. Calocedrus decurrens (Torr.) Florin

11. Carpinus betulus L.

12. Catalpa bignonioides $\mathrm{L}$.

13. Chamaecyparis lawsoniana (A. Murray) Parl.

14. Citrus $\mathrm{x}$ limon $\mathrm{L}$.

15. Fagus sylvatica L.

16. Fraxinus americana $\mathrm{L}$.

17. Fraxinus excelsior "Jaspidea Pendula"

18. Gleditsia triacanthos $\mathrm{L}$.

19. Gymnocladus dioicus C. Koch

20. Juglans nigra L.

21. Juniperus virginiana $\mathrm{L}$.

22. Larix decidua Mill.

23. Liriodendron tulipifera $\mathrm{L}$.

24. Maclura pomifera (Raf.) Schneid.

25. Magnolia sp.

26. Paulownia sp.

27. Picea abies

28. Pinus sp.

29. Pinus wallichiana A. B. Jacks

30. Platanus sp.

31. Populus alba $\mathrm{L}$.

32. Pseudotsuga sp.

33. Pterocarya $\mathrm{sp.}$

34. Quercus petraea L.

35. Quercus robur L.

36. Robinia sp.

37. Rosa $\mathrm{sp.}$

38. Salix sp.

39. Sassafras officinale Th. Nees et Eberm.

40. Styphnolobium japonicum (L.) Schoot

41. Taxodium distichum $\mathrm{L}$.

42. Taxus baccata L.

43. Tilia $\mathrm{sp}$.

44. Tsuga canadensis $\mathrm{L}$.

45. Ulmus $\mathrm{sp}$.

\section{Dvorci}

\begin{tabular}{|l|l|l|l|l|l|l|l|l|l|l|l|l|}
\hline & 10 & 11 & 12 & 13 & 14 & 15 & 16 & 17 & 18 & 19 & \\
\end{tabular}

\begin{tabular}{|c|c|c|c|c|c|c|c|c|c|c|c|c|c|c|c|c|c|c|}
\hline \begin{tabular}{l|l}
1 & 2
\end{tabular} & \begin{tabular}{l|l}
2 & 3
\end{tabular} & 3 & 4 & 5 & 6 & 7 & 8 & 9 & 10 & 11 & \begin{tabular}{l|l}
12 \\
\end{tabular} & \begin{tabular}{l|l}
13 & 1
\end{tabular} & \begin{tabular}{l|l}
14 & 1
\end{tabular} & \begin{tabular}{l|l}
5 & 11
\end{tabular} & \begin{tabular}{l|l}
6 & 17
\end{tabular} & 718 & 19 & \\
\hline+ & & & & & + & & & & + & & & & & & & & & 3 \\
\hline
\end{tabular}

\begin{tabular}{llllllll|l|l|l|l|l|l|}
\hline & \\
\hline
\end{tabular}

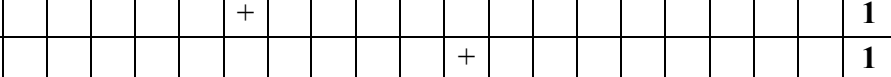

$+$

$++$

$+$\begin{tabular}{ll|l|l|ll}
+ & + & + & & + & +
\end{tabular}

(1)

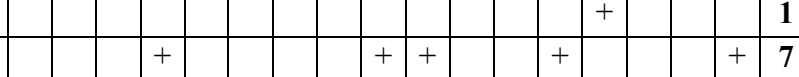

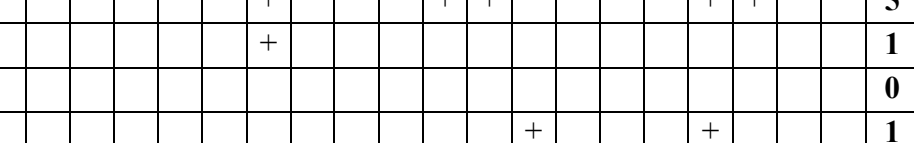

Legenda / Legend: 1. Bajnski dvori, 2 Gorica, 3. Klenovnik, 4. Velika Horvatska, 5. Bela II.,

7. Gornja Bedekovčina, 8. Gredice, 9. Jakovlje, 10. Lužnica, 11. Novi Marof, 12. Opeka, 13. Oroslavje Donje,

14. Popovec, 15. Stubički Golubovec, 16. Šaulovec, 17. Veliki Bukovec, 18. Začretje, 19. Zajezda. 
Doroteja Benko, Ivana Vitasović-Kosić / Primjena utilitarnog i ukrasnog bilja u razdoblju baroka na primjeru dvoraca Hrvatskog Zagorja / Glasilo Future (2019) 2 (5-6) 58-70

Perivoj Opeka je zaštićena prirodna rijetkost, hortikulturni spomenik koji je nastao uz dvorac Opeka, smješten je u općini Vinica. Park je podijeljen u dva dijela, prvi je donji dio-ravničarski, a drugi je dio formiran kao park-šuma koja štiti park i prostire se po brežuljcima. Kroz godine je vegetacijski je dio promijenjen i unesene su brojne egzotične vrste, ali i dalje su vidljivi elementi baroka (Slika 5.).

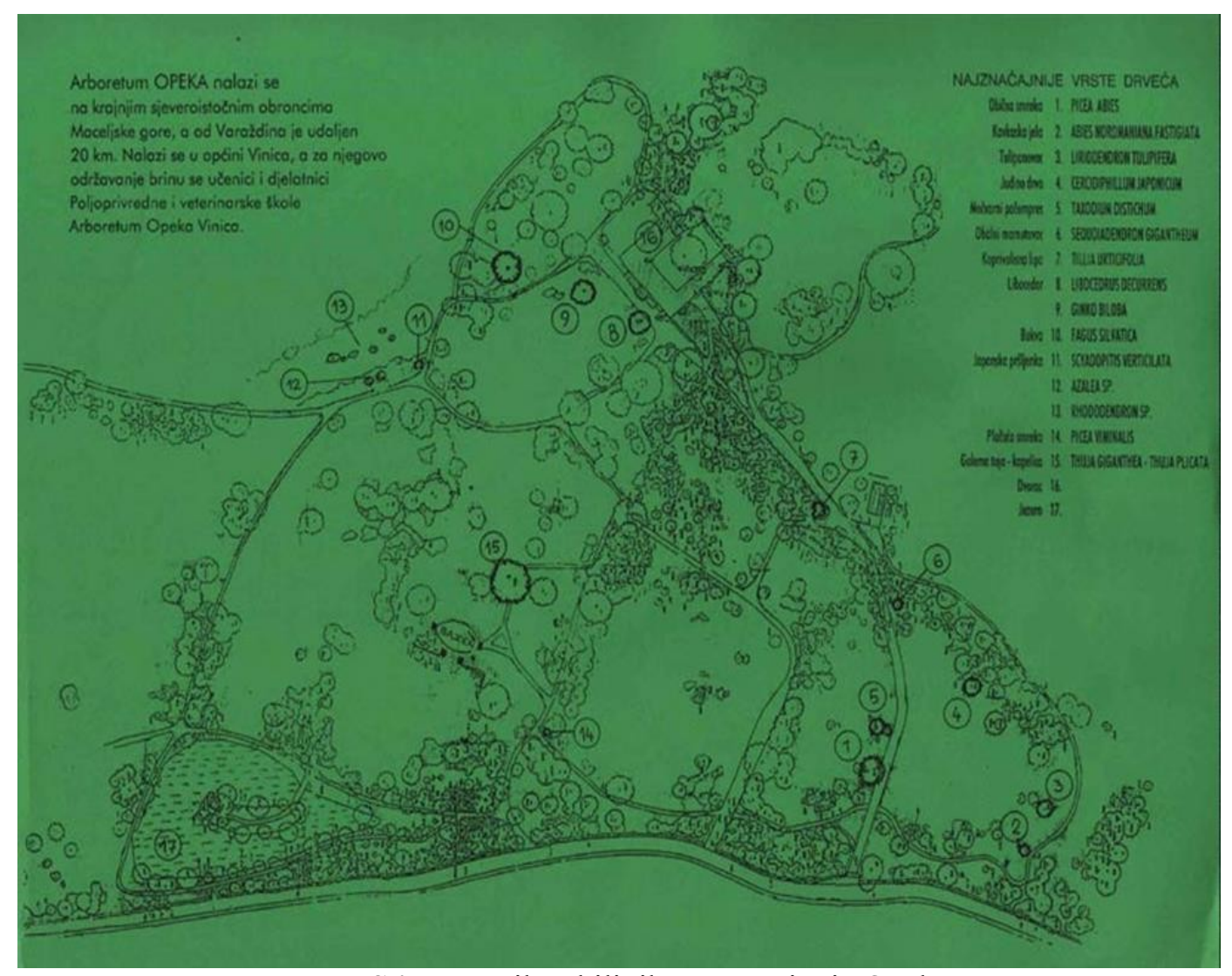

Slika 5. Prikaz biljnih vrsta perivoja Opeka

(Izvor: Landmarkings.com, http://landmarkings.com/opeka_zanimljivosti_hr.php) ${ }^{3}$.

Figure 5. Plan Opeka with plants

(Source: Landmarkings.com, http://landmarkings.com/opeka_zanimljivosti_hr.php) .

Perivoj Golubovec nalazi se u Hrvatskom zagorju, u gradu Donja Stubica, točnije istočni dio grada koji graniči s Gornjom Stubicom. Položaj perivoja i dvorca pruža se na krajnjim izduženim ograncima planinskog masiva Medvednice (podnožje-tercijarne naslage). Uz potočne doline nalaze se holocenske naslage koje se sastoje od pijeska, gline i ilovače debljine sloja od 10 do 20 metara što je sve utjecalo na odabir biljnih vrsta (Slika 6.).

Najčešće se u perivojima spominje divlji kesten (Aesculus hippocastanum L.) koji se sadio uz prilazne putove kao drvored da usmjerava putnike. Jednak razmak između jedinki divljeg kestena naglašava liniju staze, a u današnje ga vrijeme i dalje viđamo uz prometnice, glavni razlog tome je što je otporan

\footnotetext{
${ }^{3}$ LEGENDA: 1. Picea abies (L.) Karsten, 2. Abies nordmanniana (Stev.) Spach, 3. Liriodendron tulipifera L., 4. Cercidiphyllum japonicum Siebold \& Zucc., 5. Taxodium districtum (L.) Rich, 6. Sequoiadendron giganteum (Lindl.) J. Buchh., 7. Thuja pseudophakia, 8. Calocedrus decurrens (Torr.) Florin, 9. Ginkgo biloba L., 10. Sciadopitys verticillata (Thunb.) Siebold \& Zucc, 12. Azalea sp., 13. Rhododendron sp., 14. Picea sp., Thuja giganthea-Thuja plicata Donn ex D.Don
} 
Doroteja Benko, Ivana Vitasović-Kosić / Primjena utilitarnog i ukrasnog bilja u razdoblju baroka na primjeru dvoraca Hrvatskog Zagorja / Glasilo Future (2019) 2 (5-6) 58-70

na gradska onečišćenja. Od crnogorice se u perivojima najčešće spominje rod smreka (Picea sp.). Idealno je odgovarala za područja gdje se težilo cjelogodišnjem ozelenjenom prostoru. Njezina je simbolika bila čednost, ali i vječnost zbog svoje trajne tamnozelene boje, a uporan rast i vitkost simboliziraju krijepost i strpljivost (Germ, 2002). Rod platana (Platanus sp.) krasio je mnoge perivoje sa svojim vanjskim slojem kore koja se ljušti i otpada. To je bila njezina posebnost zbog koje se isticala među ostalim stablima, te slobodno može simbolizirati "elegantniji" dio perivoja dvorca što je vidljivo po njezinoj svijetlosivoj kori u odnosu na ostalo drveće tamnosive kore i grube teksture. Pružanjem svojih grana simbol je dobrotvornosti, čvrstoće karaktera i čudotvorne nadmoći (Germ, 2002). Neke inventarizirane vrste spominju se samo jednom, što navodi na zaključak da su nekadašnji vlasnici tijekom putovanja skupljali biljne vrste i donosili ih u svoje perivoje te tako postizali raskoš baroknog stila. Takve su vrste primjerice: japanska sofora (Styphnolobium japonicum L.), sazafras (Sassafras officinale Th. Neeset Eberm.), himalajski bor (Pinus wallichiana A. B. Jacks), zlatni žalosni jasen (Fraxinus excelsior "Jaspidea Pendula"), gimnoklad (Gymnocladus dioicus L). i lozarovac (Ampelopsis sp.).

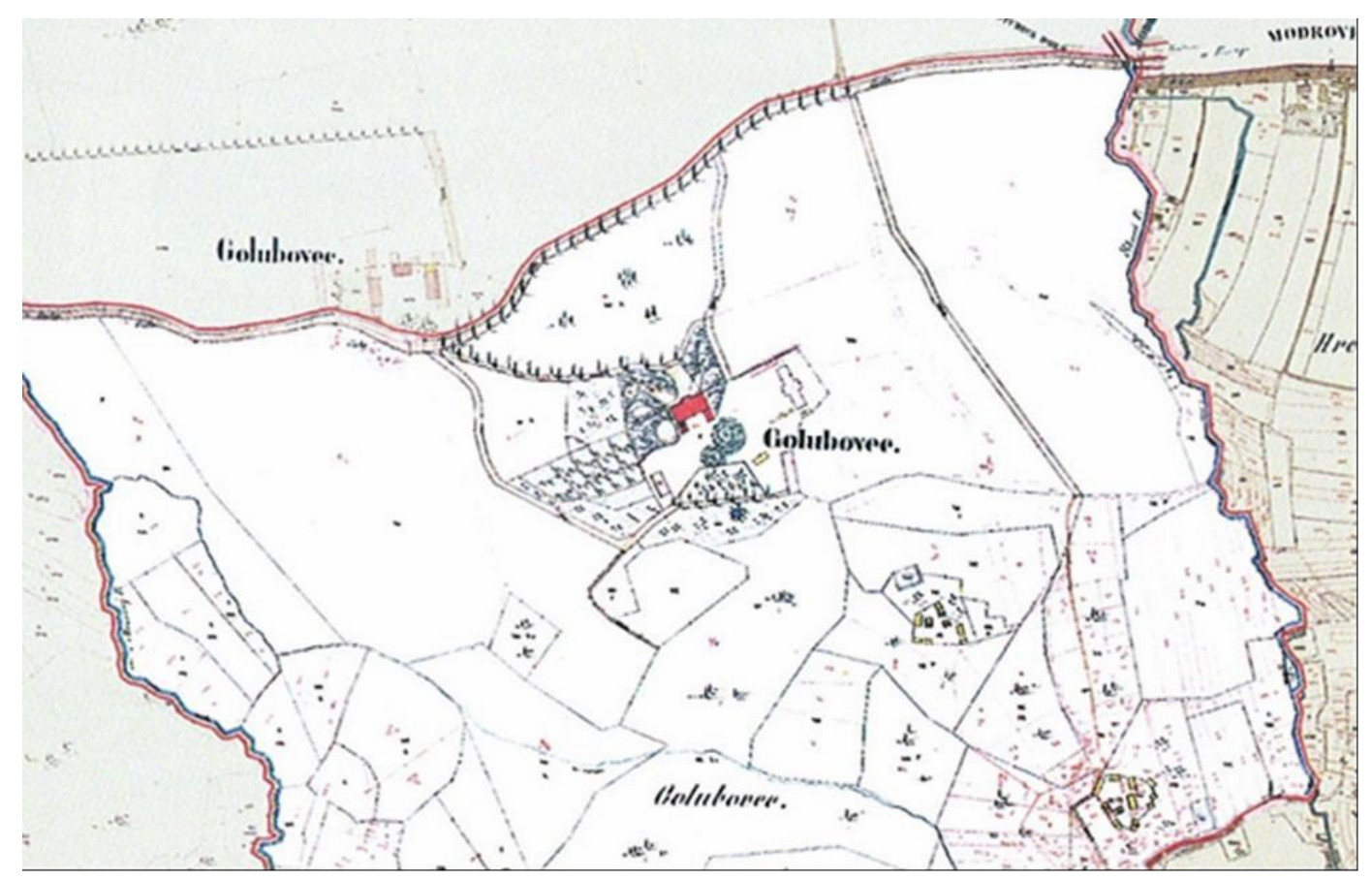

Slika 6. Katastarska karta 1861. g. (Dvorac Golubovec u Donjoj Stubici", preuzeto iz Šćitaroci (2005). Figure 6. Cadastral map of 1861 (Dvorac Golubovec u Donjoj Stubici", taken from Šćitaroci (2005).

U odabranim primjerima, Opeka i Golubovec, zabilježene su najčešće egzotične vrste s putovanja ili pak biljne vrste koje su sadili u voćnjacima. Opeka ima tri šumske zajednice (Florijanović, 2017). Veći dio pripada šumskoj zajednici hrasta kitnjaka (Quercus petraea (Mattuschka) Liebl.) i običnog graba (Carpinus betulus L.), na jačem nagibu nalazimo acidofilnu šumsku zajednicu hrasta kitnjaka (Quercus petraea) i kestena (Castanea sativa Mill.) koja je djelomično iskrčena i zasađena crnogoricom; rod duglazija (Pseudotsuga), kanadska čuga (Tsuga canadensis (L.) Carriere), bor 
(Pinus sp.) i europski ariš (Larix decidua Mill.). Na najnižem, povremeno poplavljenom dijelu perivoja, sačuvala se šuma hrasta lužnjaka (Quercus robur L.). Uz jezero su vodene i močvarne vrste, a u perivoju raste drveće i grmlje doneseno iz Japana, Kine, Tibeta, Kavkaza, Sjeverne Amerike i mnogih europskih zemalja. Osim navedenih rodova crnogorice uzgajala se još obična smreka (Picea abies (L.) Karsten), obični ili bijeli bor (Pinus sylvestris L.), obična jela (Abies alba Mill.), obična tisa (Taxus baccata Mill.) i rod tuja (Thuja). Prema Florijanović (2017) od autohtonih listača najviše se zastupljeni rod lipa (Tilia) i jasen (Fraxinus), vrste bijela topola (Populus alba L.), bijela vrba (Salix alba L.),bagrem (Robinia pseudoaccacia L.) i dr., a prisutne su i egzotične vrste kao japanski javor (Acer palmatum Thunb.), kesten (Castanea sativa Mill.), katalpa (Catalpa bignonioides Walter), crni orah (Juglans nigra L.), američki tulipanovac (Liriodendron tulipifera L.), rod magnolija (Magnolia), maklura (Maclura pomifera (Raf.) Schneid.), paulovnija (Paulownia tomentosa (Thunb.) Steud)., rod pterokarija (Pterocarya), japanska sofora (Styphnolobium japonicum (L.) Scott) i dr.

Perivoj Golubovec ima tri cjeline pejzažnog prostora dvorca: perivoj, perivojna šuma i Vilinske poljane. Eurosibirsko-sjevernoamerička regija Ilirske provincije, optimalno je stanište šume hrasta lužnjaka (Quercus robur L.) i običnog graba (Carpinus betulus L.), a uz rub vodotoka razvija se bujna sastojina koju čine crna topola (Populus nigra), bijela vrba (Salix alba L.), crvena vrba (Salix purpurea L.),vrba iva (Salix caprea L.), žalosna vrba (Salix alba "Vitelina Pendula "), sremza (Prunus padus L.) i svib (Cornus sanguinea L.). U većim jezerima zastupljen je žuti lokvanj (Nuphar lutea (L.) Sibth. et Sm.). Osim navedenih biljnih zajednica prisutne su i agrocenoze, koje je čovjek stvorio kultiviranjem šumskih i livadnih staništa. Najzastupljenije su oranice, manje površine voćnjaka jabuke (Malus domestica Borkh.), trešnje (Prunus avium L.), kruške (Pyrus communis L.), običnog oraha (Juglans regia L.), vinograda te vrtova uz obiteljske kuće i okućnice poljodjelskih gospodarstava (Šćitaroci, 2005).

\section{Zaključak}

Zaključno možemo reći da je svako povijesno razdoblje definirano tadašnjim političkim, ekonomskim, društvenim i prirodnim čimbenicima. U baroku perivoji uživaju u punoj slavi i ljepoti zahvaljujući moćnim europskim vladarima koji su ga koristili kao dobar prikaz svoje moći. Vrtovi su omogućavali drugačiji, puniji, zanimljiviji i raznolikiji način života, a s obzirom na to da je sastavljen od više strukturnih elemenata on je bio privlačan svima neovisno o dobi, statusu ili o imovinskom stanju vlasnika vrta.

Na temelju literature doznajemo kako su dvorci Hrvatskog zagorja i njihovi perivoji imali podvojene uloge; gospodarsku i stambenu. Problemi povezivanja ta dva prostora svedena su na minimalna krajobrazna rješenja. Potrebno je bilo proširiti pogled na okolni prirodni krajolik kako bi se dobila funkcionalnija (adekvatnija) slika tog prostora što je općenito zajednička karakteristika dvoraca Hrvatskog zagorja. Te male površine iskorištavali su za sadnju gospodarskih vrsta, a dekorativne su 
vrste zanemarivali. Razlika između europskog baroka i kontinentalne Hrvatske, točnije Hrvatskog zagorja izrazito je uočljiva kada gledamo veličine posjeda, namjenu vrta, ali najviše u odnosu sa prirodom. Europski barok želi vladati nad prirodom, a u Hrvatskom zagorju imamo prilagođavanje nagibu, male modelacijske preinake i nadograđivanje prostora okolnim vizurama ("posuđeni krajobraz" gdje koristimo elemente iz okruženja kako bismo nadopunili svoju sliku određenog prostora). Zaključujemo da su ljudi toga vremena koristili bilje koje ih okružuje ili koje je imalo gospodarski značaj, a drugo ukrasno bilje što se pojavljuje pojedinačno u perivojima može se pretpostaviti da je doneseno nakon putovanja pojedinih vlasnika svijetom. Značajna je bila i simbolika biljnih vrsta, no kako uvjeti za sadnju nisu bili idealni (male površine, nepovezanost zgrada i sl.), simbolika se često morala zanemarivati. Neki vidljivi simboli povezani sa Crkvom vidljivi su u pojedinim kapelicama dvoraca gdje se nosilo cvijeće za vrijeme obreda (npr. na blagdan Cvjetnicu se nosio drijen Cornus mas).

\section{Zahvala}

Rad je izrađen u okviru izrade Završnog rada studentice krajobrazne arhitekture Doroteje Benko (vidi Literaturu).

\section{Literatura}

Aničić, B. (2017). Vrt u individualnoj rezidencijalnoj arhitekturi. Zagreb: Školska knjiga.

Artnit (2015). Simbolika šimšira, dostupno na: http://www.artnit.net/flora-doma/item/2495-simbolika\%C5 \%A1im \%C5 \%A1 ira.html (pristupljeno: 20. 04. 2018.).

Banić, S., Hutinec, J. B. (2006). Drveće Maksimira, priručnik za određivanje vrsta. Zagreb: Javna ustanova "Maksimir".

Benko, D. (2018). Botanička upotreba bilja u razdoblju baroka, Završni rad, Agronomski fakultet, Sveučilište u Zagrebu.

Borak Martan, V., Šoštarić, R. (2014). The floristic composition of grassland of the Opeka arboretum (Vinica, NW Croatia), Botanički zavod s Botaničkim vrtom, Prirodoslovno-matematički fakultet, Sveučilište u Zagrebu.

Florijanović A. (2017). Povijesni i kulturni značaj arboretuma Opeke, Završni rad, Sveučilište Sjever (Sveučilišni centar Varaždin), Odjel za multimediju, Koprivnica.

Forum (2009). Simbolika cvijeća, dostupno na: http://alfaiomegaduhovniforum.forums-free.com /simbolika-cvijeca-t1584.html (pristupljeno: 15. 04. 2018.). 
Doroteja Benko, Ivana Vitasović-Kosić / Primjena utilitarnog i ukrasnog bilja u razdoblju baroka na primjeru dvoraca Hrvatskog Zagorja / Glasilo Future (2019) 2 (5-6) 58-70

Germ, T. (2002). Simbolika cvijeća (prijevod sa slovenskog Jagna Pogačnik). Zagreb: Mozaik knjiga.

Gojković, S. (2013). Simbolika cvijeća na slikama flamanskih i nizozemskih slikara u Strossmayerovoj galeriji starih majstora Hrvatske akademije znanosti i umjetnosti u Zagrebu, Diplomski rad, Sveučilište u Zagrebu, Filozofski fakultet, Odsjek za povijest umjetnosti.

Marković, V. (1987). O baroknim dvorcima u Hrvatskoj (dvije skice). Zagreb: Radovi IPU 11:143157.

Marković, V. (1995). Barokni dvorci Hrvatskog zagorja. Zagreb: Nacionalna i sveučilišna knjižnica.

Ogrin, D. (1993). Vrtna umetnost sveta. Ljubljana: Narodna in univerzitetna knjižnica.

Pađan, Z. (2012). Arhitektura biljaka, Biljke kao dio općeg evolucijskog fenomena građenja. Zagreb: Školska knjiga.

Plantea (2018). Priroda i biljke, dostupno na: https://www.plantea.com.hr/ (pristupljeno: 10. 04. 2018.).

Portal za kulturni turizam, Dvorci zagorja, dostupno na: http://www.kulturniturizam.com/hrv/sadrzaj/dvorcizagorja/ (pristupljeno: 19. 03. 2018.).

Rechner Dika, I. (2015). Razvoj krajobraznog oblikovanja, interna skripta. Zagreb: Agronomski fakultet, Sveučilište u Zagrebu.

Šćitaroci, M. O. (2005). Dvorci i perivoji Hrvatskog zagorja. Zagreb: Školska knjiga.

The Royal horticultural society (1992), Encyclopedia of Gardening, Dorling Kindersley Limited, London, prijevod: Crnetić, T. i B., Biličić, I., Biličić I. W., Vrdoljak, A., Gomaz, I., Hodak, I. (2005). Vrt, Velika ilustrirana enciklopedija. Zagreb: Mozaik knjiga.

Portal Vrt.hr - svijet kroz cvijet, Simbolika cvijeća, dostupno na: http://vrt.hr/simbolika-cvijeca/ (pristupljeno: 15. 04. 2018.).

Bojana B. (2001). Znanje, Barokna umjetnost, uvod, dostupno na: http://www.znanje.org/ i/i19/99iv03/99iv0305/ (pristupljeno: 28. 03. 2018.).

Primljeno: 02. prosinca 2019. godine

Prihvaćeno: 30. prosinca 2019. godine
Received: December 02, 2019

Accepted: December 30, 2019 